\title{
Efficacy of Everolimus Low-Dose Treatment for Cardiac Rhabdomyomas in Neonatal Tuberous Sclerosis: Case Report and Literature Review
}

\author{
Luisa Federica Nespoli ${ }^{1}$, Elena Albani ${ }^{2}$, Carla Corti ${ }^{1}$, Luigina Spaccini ${ }^{3}$, Enrico Alfei ${ }^{4}$, Irene Daniele ${ }^{5}$, \\ Gian Vincenzo Zuccotti ${ }^{2,6} \mathbb{D}^{D}$, Gianluca Lista ${ }^{5}$, Valeria Calcaterra ${ }^{2,7,+} \mathbb{D}$ and Savina Mannarino ${ }^{1, *,+}$ \\ 1 Pediatric Cardiology Unit, “Vittore Buzzi” Children's Hospital, 20154 Milano, Italy; \\ luisa.nespoli@asst-fbf-sacco.it (L.F.N.); carla.corti@asst-fbf-sacco.it (C.C.) \\ 2 Department of Pediatrics, "Vittore Buzzi" Children's Hospital, 20154 Milano, Italy; \\ elena.albani1@gmail.com (E.A.); gianvincenzo.zuccotti@unimi.it (G.V.Z.); valeria.calcaterra@unipv.it (V.C.) \\ 3 Clinical Genetics Unit, Department of Obstetrics and Gynecology, "V. Buzzi” Children's Hospital, \\ University of Milano, 20154 Milano, Italy; luigina.spaccini@asst-fbf-sacco.it \\ 4 Pediatric Neurology Unit, “V. Buzzi” Children's Hospital, Milano, 20154 Milano, Italy; \\ enrico.alfei@asst-fbf-sacco.it \\ 5 Neonatal Pathology and Neonatal Intensive Care Unit, "V. Buzzi” Children's Hospital, University of Milano, \\ 20154 Milano, Italy; irene.daniele@asst-fbf-sacco.it (I.D.); gianluca.lista@asst-fbf-sacco.it (G.L.) \\ 6 Department of Biomedical and Clinical Science "L. Sacco", University of Milano, 20157 Milano, Italy \\ 7 Pediatric and Adolescent Unit, Department of Internal Medicine, University of Pavia, 27100 Pavia, Italy \\ * Correspondence: savina.mannarino@asst-fbf-sacco.it \\ + These authors jointly and equally supervised this work.
}

Citation: Nespoli, L.F.; Albani, E.; Corti, C.; Spaccini, L.; Alfei, E.;

Daniele, I.; Zuccotti, G.V.; Lista, G.; Calcaterra, V.; Mannarino, S. Efficacy of Everolimus Low-Dose Treatment for Cardiac Rhabdomyomas in Neonatal Tuberous Sclerosis: Case Report and Literature Review. Pediatr. Rep. 2021, 13, 104-112. https:// doi.org/10.3390/pediatric13010015

Received: 14 January 2021

Accepted: 25 February 2021

Published: 1 March 2021

Publisher's Note: MDPI stays neutral with regard to jurisdictional claims in published maps and institutional affiliations.

Copyright: (c) 2021 by the authors. Licensee MDPI, Basel, Switzerland. This article is an open access article distributed under the terms and conditions of the Creative Commons Attribution (CC BY) license (https:/ / creativecommons.org/licenses/by/ $4.0 /)$.

\begin{abstract}
Background: Cardiac rhabdomyomas (CRs) are the most common cardiac tumors in newborns. Approximately $80-90 \%$ of cases are associated with tuberous sclerosis complex (TSC). In selective cases, Everolimus has resulted in a remarkable tumoral regression effect in children with TS. The optimal dosage for neonates is still unknown. Case presentation: We describe the use of Everolimus in a neonate with multiple biventricular CRs, causing subaortic obstruction, in which a low-dose treatment $(0.1 \mathrm{mg} / \mathrm{die})$, in an effort to maintain serum trough levels of $3-7 \mathrm{ng} / \mathrm{mL}$, was successfully used off-label, without adverse effects. Conclusions: We showed that a low-dose Everolimus regimen may be an effective and safe treatment for CR regression in TS neonates, when the minimum therapeutic range was maintained.
\end{abstract}

Keywords: cardiac rhabdomyoma; tuberous sclerosis; everolimus; neonate; low dose

\section{Introduction}

Tuberous sclerosis complex (TSC) is a rare autosomal dominant genetic disorder, characterized by over-activation of the mammalian target of the rapamycin (mTOR) pathway [1,2]. Recent studies estimate a frequency of $1 / 6000-1 / 10,000$ of live births and a population prevalence of around 1/20,000 [1,2]. This genetic disorder leads to the growth of hamartomas in multiple organs, such as the skin, central nervous system, angiofibromas, renal angiomyolipoma, and cardiac rhabdomyomas (CRs) [2,3].

CRs account for up to $90 \%$ of cardiac tumors in the pediatric population under the age of 1 and are associated with TSC in 60-80\% of the cases [3,4].

Everolimus is a serine-threonine kinase mammalian target of rapamycin inhibitor, which is able to inhibit growth-driven cell proliferation [5,6]. Everolimus is currently approved by the Food and Drug Administration (FDA) and the European Medicines Agency for TSC-associated partial-onset seizures, subependymal giant cell astrocytoma, and renal angiomyolipoma in children [7,8]. Everolimus has been successfully used offlabel in pediatric case reports of symptomatic CRs associated with TSC [7-9]. The optimal dosage for neonates is still unknown and is currently under debate [3,5,10-21]. 
We described the use of Everolimus in a neonate with multiple biventricular CRs, in which a low-dose treatment was successfully adopted, maintaining a minimum therapeutic range. A literature review of the low-dose drug treatment during the neonatal period was also carried out.

\section{Case Presentation}

A full-term male infant was born at $40+4$ gestational weeks, with a birth weight of $4660 \mathrm{~g}$ and a normal perinatal adaptation. No remarkable family history for neurologic pathologies or symptoms suggestive of TSC was recorded.

He underwent echocardiography on the first day of life for the presence of a cardiac murmur 3/6 left (L) on the precordium. At the first cardiologic visit, the baby revealed good clinical conditions, with normal blood pressure and heart rate of $142 \mathrm{bpm}$. ECG readings were normal. The echocardiographic evaluation showed normal biventricular dimensions and systolic function, with multiple highly echogenic cardiac masses. In particular, the following lesions were located: One in the medium-apical portion of the interventricular septum $(7 \times 2 \mathrm{~mm})$; three multi-lobular shaped lesions on the mitral valve chordae $(7 \times 3 \mathrm{~mm} ; 8.5 \times 3.5 \mathrm{~mm} ; 16 \times 4 \mathrm{~mm})$, leading to a mild acceleration of left ventricular output $(\mathrm{v} \max 2.4 \mathrm{~m} / \mathrm{s})$; one in the left ventricular apex $(8.5 \times 2.5 \mathrm{~mm})$; one in the mid-apical segment of the right ventricle area $\left(0.6 \mathrm{~cm}^{2}, 7 \times 8 \mathrm{~mm}\right.$ in apical view); and one in the subaortic region $\left(10 \times 10 \mathrm{~mm}\right.$, area $0.7 \mathrm{~cm}^{2}$ in apical view), originating from the outlet septum, extending towards the mitral valve, with a tiny $1.5 \mathrm{~mm}$ space for blood passage between the mass and the non-coronary aortic cusp, leading to an elevated pressure gradient in the left outflow tract (grad max/medium 60/40 mm Hg), Figure 1.

A diagnosis of multiple CRs was made. The baby was transferred to the Neonatal Intensive Care Unit for continuous cardiac monitoring. In the hypothesis of CRs associated with TSC, a cerebral MRI, abdominal ultrasound, EEG, eye and dermatological examinations were performed, all of which resulted negative. The genetic screening of the proband and parents revealed a de novo pathognomonic mutation in the TSC2 gene.

The baby remained asymptomatic, with excellent weight gain and no feeding difficulties. ECG monitoring revealed no cardiac arrhythmia. Nonetheless, due to the location and number of cardiac tumors, we decided to begin a low-dosage administration of propanolol $(1.5 \mathrm{mg} / \mathrm{kg} /$ die orally), which was well tolerated.

Due to the severe gradient in the left ventricular outlet, the clinical case was discussed with cardiac surgeons. Considering the high risk of complications, they decided not to perform resection of the subaortic mass.

After a multidisciplinary consultation meeting with cardiologists, neonatologists, a neurologist, and a geneticist, the parents agreed to begin the off-label Everolimus therapy. The baby was given Everolimus, $0.1 \mathrm{mg} /$ die per os, starting at 26 days.

The serum Everolimus level 5 days after the initial dose was $4.5 \mathrm{ng} / \mathrm{mL}$, the baby was well and the intensity of the cardiac murmur had dropped to 1-2/6 L. The CRs had already begun to shrink: The subaortic mass shrank to $6.5 \times 9 \mathrm{~mm}$, with a $2.7 \mathrm{~mm}$ space between the mass and the aortic wall; the transaortic pressure gradient halved to $24 / 14 \mathrm{mmHg}$, with no acceleration of the left ventricular output.

After 1 week, the serum Everolimus level was $4.4 \mathrm{ng} / \mathrm{mL}$. The infant did not suffer any collateral effects, weight gain was steady, ECG was always normal, without arrhythmia. The cardiac masses continued to shrink with only a slightly elevated transaortic gradient $(25 / 11 \mathrm{mmHg})$, Figure 2. After only 2 weeks, the transaortic velocity was normal. The masses continued to shrink over the next few months, even though the plasmatic dosage of Everolimus was always at the inferior level of around $3 \mathrm{ng} / \mathrm{mL}$. The child suffered no collateral effects (no major infections, no aftae, normal blood cell count) and neurological evaluations were always normal. 


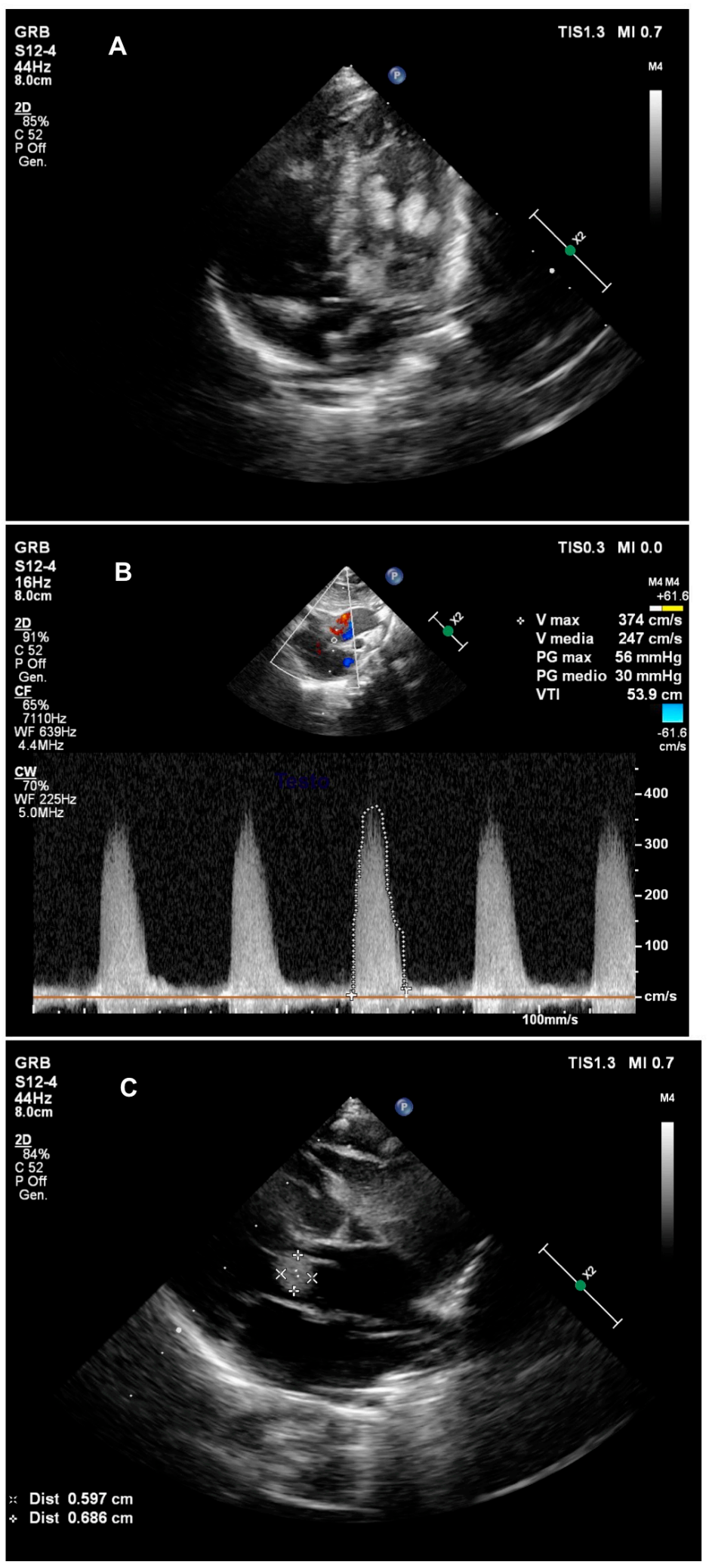

Figure 1. Echocardiogram on the first day of life. Panel (A): Left ventricle rhabdomyomas; Panel (B): Elevated transaortic gradient; Panel (C): Subaortic mass. 

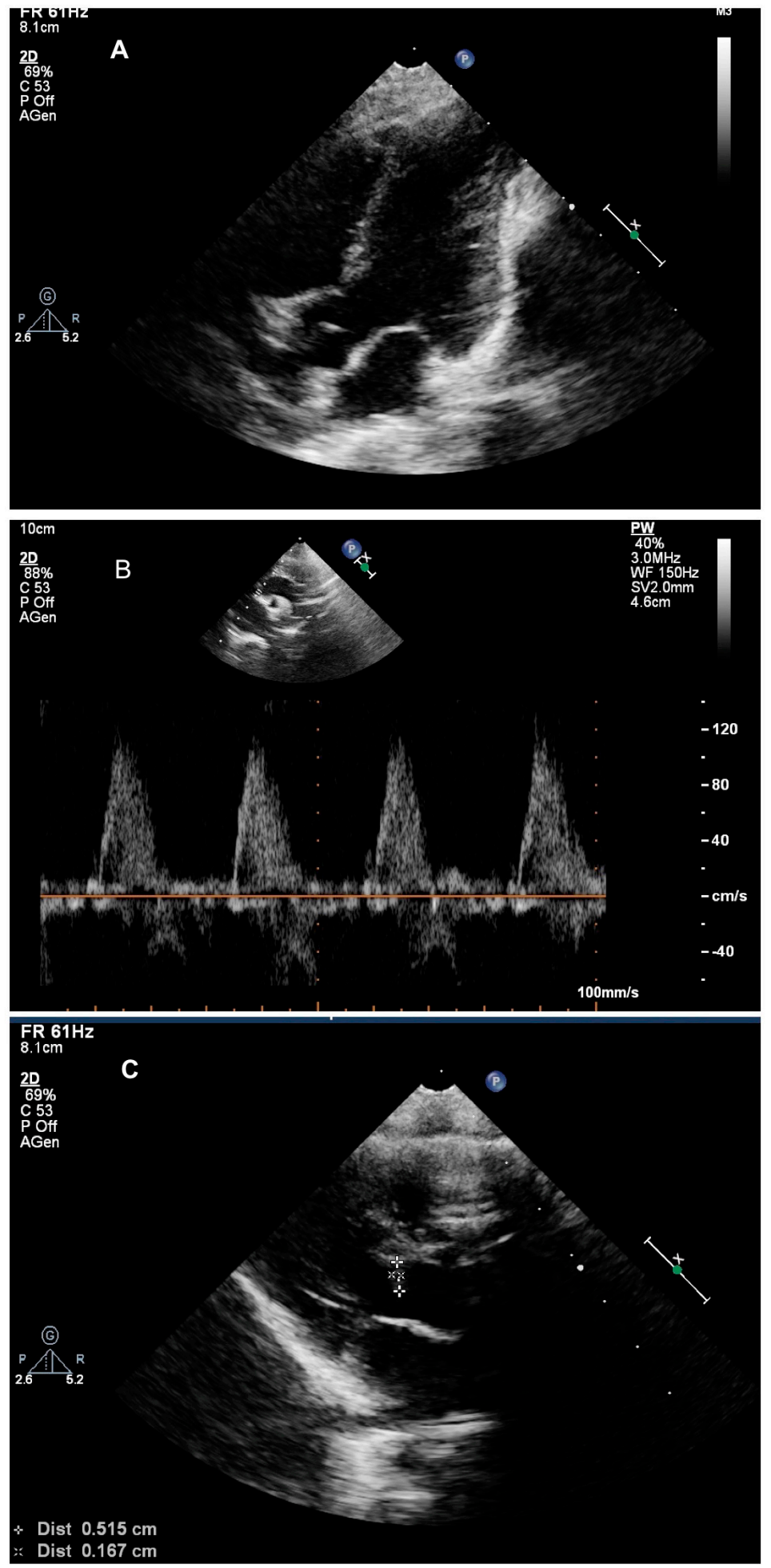

Figure 2. Echocardiogram after 1 week of Everolimus treatment. Panel (A): Disappearance of the left ventricle rhabdomyomas; Panel (B): Normal transaortic gradient; Panel (C): Marked reduction of the subaortic mass.

After 6 months of therapy, an echocardiogram revealed that the mass in the interventricular septum and the masses attached to the mitral chordae were not visible, the subaortic mass was $5 \times 2 \mathrm{~mm}$, blood passage was normal, as were the transaortic gradients. The right intraventricular mass had almost completely disappeared. Thus, the Everolimus therapy was discontinued. 
Three weeks later, at the ultrasound evaluation the subaortic mass was found to be stable, with normal gradients. The right intraventricular mass and the ones attached to the mitral chordae were visible, but small and not hemodynamically significant. Therefore, we decided not to begin therapy again and planned a monthly echocardiographic follow-up. The baby was asymptomatic, in good clinical conditions, with normal weight gain, and had never contracted infectious diseases.

\section{Discussion}

$\mathrm{CR}$ is the most common primary cardiac pediatric tumor and is a major criterion for TSC diagnosis [1,3]. Most patients with CRs and TSC are asymptomatic, and tumors slowly and spontaneously regress in the first 2 years of life in half of the cases. Some patients become symptomatic and require treatment, with symptoms ranging from arrhythmia and intracardiac blood flow obstruction to congestive heart failure, depending on the size, number, and location of the tumor/s [1,3].

The current standard therapy for symptomatic patients is supportive care (diuretics, intravenous inotropic drugs, antiarrhythmics) [1,4]. Surgery is recommended in severe cases, for large tumors that obstruct the outflow tracts of the great arteries or for arrhythmias with a very difficult medical management (generated by infiltration of the tumor and which compromise the nervous conduction) [1,4]. Cardiac surgery involves a number of potential complications such as difficulty in resecting all the tumors, long stays in the intensive care unit, and a high risk of mortality. Moreover, in some cases, considering the size, location, and relation with coronary arteries or intracardiac valves, tumors may be inoperable. Patients with multiple and inoperable CRs may be candidates for the Everolimus treatment.

Everolimus, a mammalian target of the rapamycin inhibitor drug, has the ability to reduce hamartomas, correcting the specific molecular defect that causes TSC. Everolimus has demonstrated a remarkable suppression effect in children with TSC at doses of $4.7-5.6 \mathrm{mg} / \mathrm{m}^{2} /$ day and serum trough levels of $5-15 \mathrm{ng} / \mathrm{mL}[22,23]$.

We described the use of Everolimus in a neonate with multiple biventricular CRs, in which a low-dose drug treatment was successfully adopted, maintaining a minimum therapeutic range.

In the literature, Everolimus therapy in CRs associated with TS has been described in 25 cases occurring in the neonatal period (Table 1 ). The dosage reported ranged between $0.1-0.5 \mathrm{mg} /$ day although an optimal dosage for neonates is still unknown. As described in Table 1, an initial low dose (0.08-0.1 mg/day) of Everolimus was adopted in only nine neonates. A significant reduction was evident as early as 4 weeks after starting the treatment. Similarly to reports from Chang et al. [15], in our case, the cardiac masses rapidly diminished and after only 5 days of therapy they became clinically insignificant. Of these nine neonates, in seven cases a therapeutic range of 5-15 ng/mL was maintained. In two cases, as in our neonate, a minimum therapeutic range of $3-8 \mathrm{ng} / \mathrm{mL}$ was adopted, reducing the risk of toxicity. 
Table 1. Characterization of patients with cardiac rhabdomyomas treated with low doses of Everolimus in the neonatal period.

\begin{tabular}{|c|c|c|c|c|c|c|c|c|}
\hline $\begin{array}{l}\text { First Author, } \\
\text { Year }\end{array}$ & Age at Treatment & Clinical Presentation & Echographic Data at Diagnosis & Everolimus Dose & $\begin{array}{l}\text { Target Drug } \\
\text { Levels }\end{array}$ & Reported Evolution & $\begin{array}{l}\text { Adverse } \\
\text { Effects }\end{array}$ & Follow Up \\
\hline \multicolumn{9}{|c|}{ LOW-DOSE TREATMENT ( $\leq 0.1 \mathrm{mg} / \mathrm{die})$} \\
\hline $\begin{array}{l}\text { Garg A et al., } \\
2019\end{array}$ & 4th day of life & $\begin{array}{l}\text { Prenatal diagnosis of CRs } \\
\text { At birth: Pre-excitation with } \\
\text { ventricular tachycardia }\end{array}$ & $\begin{array}{l}\text { Multiple CRs (major in RV } \\
\text { free wall) }\end{array}$ & $0.08 \mathrm{mg} / \mathrm{die}$ & $3-7 \mathrm{ng} / \mathrm{mL}$ & $\begin{array}{l}\text { Improvement of } \\
\text { ventricular } \\
\text { tachycardia after } \\
4 \text { days of treatment }\end{array}$ & None & Not reported \\
\hline $\begin{array}{l}\text { Castro-Monsalve } \\
\text { J et al., } 2018\end{array}$ & Not reported & Cardiac arrest & $\begin{array}{l}\text { Multiple CRs on interventricular } \\
\text { septum with LVOTO }\end{array}$ & $0.1 \mathrm{mg} / \mathrm{die}$ & $5-8 \mathrm{ng} / \mathrm{mL}$ & $\begin{array}{l}60 \% \text { reduction of } \\
\mathrm{CR} \text { at } \\
31 \text { days-resolution } \\
\text { at } 4 \text { weeks }\end{array}$ & None & Not reported \\
\hline Aw F et al., 2016 & $\begin{array}{l}\text { Average: } 6.5 \text { days } \\
\text { (2-20 days) }\end{array}$ & $\begin{array}{c}\text { LVOTO } \\
\text { 3rd case: } \\
\text { Subependymal lesion }\end{array}$ & $\begin{array}{l}\text { 1st case: LVOTO e RVOTO } \\
\text { 2nd case: Multiple } \\
\text { CRs-major subaortic } \\
\text { 3rd case: Multiple CRs } \\
\text { 4th case: CRs with LVOTO }\end{array}$ & $0.1 \mathrm{mg} / \mathrm{die}$ & $5-15 \mathrm{ng} / \mathrm{mL}$ & $\begin{array}{l}50 \% \text { reduction of } \\
\text { CRs in } 36 \text { days }\end{array}$ & Not reported & $\begin{array}{l}\text { Treatment: } \\
\text { Average } 73 \text { days } \\
\text { (34-138 days) }\end{array}$ \\
\hline $\begin{array}{l}\text { Goyer I et al., } \\
2015\end{array}$ & $\begin{array}{l}\text { Three cases: First } \\
\text { week of life }\end{array}$ & $\begin{array}{c}\text { LVOTO } \\
\text { In one case: } \\
\text { Subependymal astrocytoma }\end{array}$ & $\begin{array}{l}\text { 1st case: Multiple CRs (n 6) } \\
\text { 2nd case: Multiple CRs } \\
\text { with LVOTO } \\
\text { 3rd case: Multiple CRs }\end{array}$ & $0.1 \mathrm{mg} / \mathrm{die}$ & $5-15 \mathrm{ng} / \mathrm{mL}$ & $\begin{array}{l}\text { Regression at } \\
1 \text { month }\end{array}$ & $\begin{array}{l}\text { Viral infection } \\
\text { in one case }\end{array}$ & $\begin{array}{c}\text { Check } \\
\text { Everolimus } \\
\text { plasmatic } \\
\text { concentration } \\
\text { every } 4 \text { days at } \\
\text { the beginning }\end{array}$ \\
\hline \multicolumn{9}{|c|}{ DOSE TREATMENT (>0.1 mg/die) } \\
\hline $\begin{array}{l}\text { Dhulipudi B } \\
\text { et al., } 2019\end{array}$ & $\begin{array}{l}\text { Average: } 5 \text { days } \\
\text { (1-90 days) }\end{array}$ & $\begin{array}{c}\text { Five case reports describing } \\
\text { cardiovascular failure due to } \\
\text { outlet obstruction }\end{array}$ & $\begin{array}{l}\text { 1st case: CR } 24 \mathrm{~mm} \text { at right outlet } \\
\text { 2nd case: CR } 13 \mathrm{~mm} \text { in right } \\
\text { atrium with superior vena } \\
\text { cava obstruction } \\
\text { 3rd case: CR } 12 \mathrm{~mm} \text { with LVOTO } \\
\text { 4th and 5th case: Multiple CRs in } \\
\text { right ventricle }\end{array}$ & $\begin{array}{l}4.5 \mathrm{mg} / \mathrm{m}^{2} / \text { week } \\
\text { divided in } \\
\text { daily doses }\end{array}$ & 5-15 ng/mL & $\begin{array}{l}\text { CR regression in } \\
6.1+/-5.1 \text { months }\end{array}$ & $\begin{array}{l}\text { Chickenpox } \\
\text { infection }\end{array}$ & Not reported \\
\hline $\begin{array}{l}\text { Shibata Y et al., } \\
2019\end{array}$ & 4th day of life & Prenatal diagnosis of $\mathrm{CR}$ & Multiple CRs with LVOTO & $\begin{array}{c}\text { Initial dose: } \\
0.4 \mathrm{mg} / \text { die, reduced to } \\
0.1 \mathrm{mg} / \text { die at day } 10\end{array}$ & $5-15 \mathrm{ng} / \mathrm{mL}$ & $\begin{array}{l}\text { Reduction of } C R \\
\text { after } 7 \text { days } \\
\text { of therapy }\end{array}$ & $\begin{array}{l}\text { Coagulopathy } \\
\text { at day } 3 \\
\text { of therapy }\end{array}$ & Not reported \\
\hline $\begin{array}{l}\text { Martinez-Garcia } \\
\text { A et al., } 2018\end{array}$ & 36 days of life & $\begin{array}{l}\text { Prenatal diagnosis of } \\
\text { multiple CRs }\end{array}$ & $\begin{array}{l}\text { Multiple CRs-major in left } \\
\text { ventricle with LVOTO }\end{array}$ & $\begin{array}{c}0.25 \mathrm{mg} \text { twice per } \\
\text { day-twice per week }\end{array}$ & Not indicated & $\begin{array}{l}\text { Improvement after } \\
2 \text { weeks of treatment }\end{array}$ & None & Not reported \\
\hline $\begin{array}{l}\text { Chang JS et al., } \\
2017\end{array}$ & Not reported & $\begin{array}{l}\text { Prenatal diagnosis of CRs } \\
\text { In one case: Seizures }\end{array}$ & $\begin{array}{l}\text { 1st case: CRs in both ventricles } \\
\text { 2nd case: CR in LV with LVOTO } \\
\text { 3rd case: Multiple CRs in } \\
\text { left ventricle }\end{array}$ & $0.3-0.67 \mathrm{mg} / \mathrm{m}^{2} /$ die & $3-7 \mathrm{ng} / \mathrm{mL}$ & $\begin{array}{l}\text { Regression in } \\
2 \text { months }\end{array}$ & $\begin{array}{l}\text { 1st case: Viral } \\
\text { pneumonia } \\
\text { 3rd case: } \\
\text { Growth failure }\end{array}$ & Not reported \\
\hline
\end{tabular}


Table 1. Cont.

\begin{tabular}{|c|c|c|c|c|c|c|c|c|}
\hline $\begin{array}{l}\text { First Author, } \\
\text { Year }\end{array}$ & Age at Treatment & Clinical Presentation & Echographic Data at Diagnosis & Everolimus Dose & $\begin{array}{l}\text { Target Drug } \\
\text { Levels }\end{array}$ & Reported Evolution & $\begin{array}{c}\text { Adverse } \\
\text { Effects }\end{array}$ & Follow Up \\
\hline $\begin{array}{l}\text { Colaneri M et al., } \\
2016\end{array}$ & Not reported & $\begin{array}{l}\text { Prenatal diagnosis of CRs } \\
\text { At birth: Hypoplastic left } \\
\text { heart syndrome }\end{array}$ & $\begin{array}{l}\text { Multiple CRs-major on left } \\
\text { ventricle free wall }\end{array}$ & $0.25 \mathrm{mg} / \mathrm{die}$ & $5-15 \mathrm{ng} / \mathrm{mL}$ & $\begin{array}{l}\text { After } 10 \text { weeks: } \\
80 \% \text { reduction } \\
\text { of CRs }\end{array}$ & None & $\begin{array}{c}\text { Stop treatment } \\
11 \text { weeks post } \\
\text { treatment }\end{array}$ \\
\hline $\begin{array}{l}\text { Bornaun } \mathrm{H} \text { et al., } \\
2016\end{array}$ & Not reported & $\begin{array}{l}\text { Cardiovascular failure due } \\
\text { to LVOTO }\end{array}$ & CR with LVOTO & $\begin{array}{l}0.5 \mathrm{mg} / \text { die twice } \\
\text { per week }\end{array}$ & $2.6-6.1 \mathrm{ng} / \mathrm{mL}$ & $\begin{array}{l}\text { Regression of lesion } \\
\text { in } 4 \text { weeks }\end{array}$ & $\begin{array}{c}\text { TG and } \\
\text { cholesterol } \\
\text { levels } \\
\text { increased. } \\
\text { Change in } \\
\text { lymphocyte } \\
\text { subgroups }\end{array}$ & $\begin{array}{l}\text { Stopped therapy } \\
\text { after } 7.5 \text { months } \\
\text { of treatment }\end{array}$ \\
\hline $\begin{array}{l}\text { Choudhry S } \\
\text { et al., } 2015\end{array}$ & 2 weeks of life & Cardiac and cerebral lesions & Multiple RCs & Not reported & Not reported & $\begin{array}{l}\text { CR regression in } \\
1 \text { month }\end{array}$ & Not reported & Not noted \\
\hline $\begin{array}{l}\text { Wagner R et al., } \\
2015\end{array}$ & Not reported & At birth: Heart murmur & Multiple CRs-major on LVOTO & $\begin{array}{c}\text { Starting dose } \\
1.5 \mathrm{mg} / \mathrm{m}^{2} / \text { die, } \\
\text { reduced to } \\
1 \mathrm{mg} / \mathrm{m}^{2} / \text { die at } \\
4 \text { th day }\end{array}$ & $5-15 \mathrm{ng} / \mathrm{mL}$ & $\begin{array}{l}\text { Progressive } \\
\text { reduction of RCs }\end{array}$ & $\begin{array}{c}\text { Slightly } \\
\text { elevated } \\
\text { triglycerides } \\
\text { and transitory } \\
\text { lymphopenia } \\
\end{array}$ & $\begin{array}{c}\text { Stop therapy at } \\
19 \text { days post } \\
\text { treatment }\end{array}$ \\
\hline $\begin{array}{l}\text { Dogan V et al., } \\
2015\end{array}$ & 2 days & $\begin{array}{l}\text { Heart murmur and } \\
\text { cardiovascular failure }\end{array}$ & CRs with LVOTO & $\begin{array}{c}0.25 \mathrm{mg} \text { twice per } \\
\text { day-twice per week }\end{array}$ & $5-15 \mathrm{ng} / \mathrm{mL}$ & $\begin{array}{l}\text { Progressive } \\
\text { reduction of RCs }\end{array}$ & Not reported & $\begin{array}{l}\text { Stop therapy at } \\
3 \text { months }\end{array}$ \\
\hline $\begin{array}{l}\text { Oztunc F et al., } \\
2014\end{array}$ & First week of life & Supraventricular tachycardia & $\begin{array}{l}\text { Multiple CRs (interventricular } \\
\text { sept—anterior wall RV) }\end{array}$ & $\begin{array}{c}0.25 \mathrm{mg} \text { twice per } \\
\text { day—twice per week }\end{array}$ & Not noted & $\begin{array}{c}\text { Supraventricular } \\
\text { tachycardia } \\
\text { resolution on day } 8 . \\
\text { Regression of RCs at } \\
15 \text { days }\end{array}$ & None & Not reported \\
\hline
\end{tabular}

CR: Cardiac rhabdomyoma; LVOTO: Left ventricular outflow tract obstruction; RVOTO: Right ventricular outflow tract obstruction; RV: Right ventricle. 


\section{Conclusions}

In this paper, we show that a low Everolimus dose may be useful to treat CRs in TSC, without any adverse effects and with excellent response to therapy. The extension of Everolimus use for a low-dose treatment of cardiac lesions with a high risk of decompensation, could be considered during the neonatal period.

Author Contributions: Conceptualization, L.F.N., E.A. (Elena Albani), C.C., V.C. and S.M.; investigation, L.F.N., E.A. (Elena Albani), C.C., L.S., E.A. (Enrico Alfei), I.D., G.L. and S.M.; writing-original draft preparation, L.F.N., E.A. (Elena Albani), C.C., L.S., E.A. (Enrico Alfei), I.D., G.V.Z., G.L., V.C. and S.M.; writing-review and editing L.F.N., E.A. (Elena Albani), C.C., L.S., E.A. (Enrico Alfei), I.D., G.V.Z., G.L., V.C. and S.M. All authors have read and agreed to the published version of the manuscript.

Funding: The authors received no financial support from public, commercial, or not-for-profit agencies to conduct this.

Institutional Review Board Statement: Not applicable.

Informed Consent Statement: The data for this case report were collected in accordance with the Declaration of Helsinki. The patient gave his informed consent to publish his case.

Data Availability Statement: All data are reported in the case.

Acknowledgments: The authors thank Sheila McVeigh for the English revision of the manuscript.

Conflicts of Interest: The authors declare no conflict of interest.

\section{References}

1. Wataya-Kaneda, M.; Uemura, M.; Fujita, K.; Hirata, H.; Osuga, K.; Kagitani-Shimono, K.; Nonomura, N. Tuberous Sclerosis Complex Board of Osaka University Hospital. Tuberous sclerosis complex: Recent advances in manifestations and therapy. Int. J. Urol. 2017, 24, 681-691. [CrossRef]

2. Portocarrero, L.K.L.; Quental, K.N.; Samorano, L.P.; Oliveira, Z.N.P.; Rivitti-Machado, M.C.D.M. Tuberous sclerosis complex: Review based on new diagnostic criteria. Bras Dermatol. 2018, 93, 323-331. [CrossRef]

3. Castro-Monsalve, J.; Alvarado-Socarras, J.L.; Mantilla, K.A.; Forero, L.; Moreno, A.; Prada, C.E. Cardiac Rhabdomyomas in Tuberous sclerosis complex. J. Pediatr. 2018, 192, 264-e1. [CrossRef] [PubMed]

4. Kwiatkowska, J.; Wałdoch, A.; Meyer-Szary, J.; Potaż, P.; Grzybiak, M. Cardiac tumors in children: A 20-year review of clinical presentation, diagnostics and treatment. Adv. Clin. Exp. Med. 2017, 26, 319-326. [CrossRef]

5. Aw, F.; Goyer, I.; Raboisson, M.J.; Boutin, C.; Major, P.; Dahdah, N. Accelerated Cardiac Rhabdomyoma regression with Everolimus in infants with tuberous sclerosis complex. Pediatr. Cardiol. 2017, 38, 394-400. [CrossRef]

6. Franz, D.N.; Capal, J.K. mTOR inhibitors in the pharmacologic management of tuberous sclerosis complex and their potential role in other rare neurodevelopmental disorders. Orphanet J. Rare Dis. 2017, 12, 51. [CrossRef]

7. Bevacqua, M.; Baldo, F.; Pastore, S.; Valencic, E.; Tommasini, A.; Maestro, A.; Rabusin, M.; Arbo, A.; Barbi, E. Off-label use of Sirolimus and Everolimus in a Pediatric Center: A case series and review of the literature. Paediatr. Drugs 2019, 21, 185-193. [CrossRef]

8. Northrup, H.; Krueger, D.A. Tuberous sclerosis complex diagnostic criteria update: Recommendations of the 2012 International Tuberous Sclerosis Complex Consensus Conference. Pediatr. Neurol. 2013, 49, 243-254. [CrossRef]

9. Hinton, R.B.; Prakash, A.; Romp, R.L.; Krueger, D.A.; Knilans, T.K. Cardiovascular manifestations of tuberous sclerosis complex and summary of the revised diagnostic criteria and surveillance and management recommendations from the International Tuberous Sclerosis Consensus Group. J. Am. Heart Assoc. 2014, 3, e001493. [CrossRef] [PubMed]

10. Garg, A.; Gorla, S.R.; Kardon, R.E.; Swaminathan, S. Rapid Involution of Large Cardiac Rhabdomyomas With Everolimus Therapy. World J. Pediatr. Congenit Heart Surg. 2019, 2150135118822711. [CrossRef] [PubMed]

11. Goyer, I.; Dahdah, N.; Major, P. Use of mTOR inhibitor everolimus in three neonates for treatment of tumors associated with tuberous sclerosis complex. Pediatr. Neurol. 2015, 52, 450-453. [CrossRef] [PubMed]

12. Dhulipudi, B.; Bhakru, S.; Rajan, S.; Doraiswamy, V.; Koneti, N.R. Symptomatic improvement using everolimus in infants with cardiac rhabdomyoma. Ann. Pediatr. Cardiol. 2019, 12, 45-48.

13. Shibata, Y.; Maruyama, H.; Hayashi, T.; Ono, H.; Wada, Y.; Fujinaga, H.; Fujino, S.; Nagasawa, J.; Amari, S.; Tsukamoto, K.; et al. Effect and Complications of Everolimus Use for Giant Cardiac Rhabdomyomas with Neonatal Tuberous Sclerosis. AJP Rep. 2019, 9, e213-e217. [CrossRef]

14. Martínez-García, A.; Michel-Macías, C.; Cordero-González, G.; Escamilla-Sánchez, K.I.; Aguinaga-Ríos, M.; Coronado-Zarco, A.; Cardona-Pérez, J.A. Giant left ventricular rhabdomyoma treated successfully with everolimus: Case report and review of literature. Cardiol. Young 2018, 28, 903-909. [CrossRef] [PubMed] 
15. Chang, J.S.; Chiou, P.Y.; Yao, S.H.; Chou, I.C.; Lin, C.Y. Regression of Neonatal Cardiac Rhabdomyoma in Two Months Through Low-Dose Everolimus Therapy: A Report of Three Cases. Pediatr. Cardiol. 2017, 38, 1478-1484. [CrossRef]

16. Colaneri, M.; Quarti, A.; Pozzi, M. Everolimus-induced near-resolution of giant cardiac rhabdomyomas and large renal angiomyolipoma in a newborn with tuberous sclerosis complex. Cardiol. Young 2016, 26, 1025-1028. [CrossRef] [PubMed]

17. Choudhry, S.; Nguyen, H.H.; Anwar, S. Rapid resolution of cardiac rhabdomyomas following everolimus therapy. BMJ Case Rep. 2015, 2015, bcr2015212946.

18. Wagner, R.; Riede, F.T.; Seki, H.; Hornemann, F.; Syrbe, S.; Daehnert, I.; Weidenbach, M. Oral Everolimus for Treatment of a Giant Left Ventricular Rhabdomyoma in a Neonate-Rapid Tumor Regression Documented by Real Time 3D Echocardiography. Echocardiography 2015, 32, 1876-1879. [CrossRef]

19. Doğan, V.; Yeşil, Ş.; Kayalı, Ş.; Beken, S.; Özgür, S.; Ertuğrul, İ.; Bozkurt, C.; Örün, U.A.; Karademir, S. Regression of symptomatic multiple cardiac rhabdomyomas associated with tuberous sclerosis complex in a newborn receiving everolimus. J. Trop. Pediatr. 2015, 61, 74-77.

20. Öztunç, F.; Atik, S.U.; Güneş, A.O. Everolimus treatment of a newborn with rhabdomyoma causing severe arrhythmia. Cardiol. Young 2015, 25, 1411-1414. [CrossRef]

21. Tiberio, D.; Franz, D.N.; Phillips, J.R. Regression of a cardiac rhabdomyoma in apatient receiving everolimus. Pediatrics 2011, 127, e1335-e1337. [CrossRef] [PubMed]

22. Dahdah, N. Everolimus for the Treatment of Tuberous Sclerosis Complex-Related Cardiac Rhabdomyomas in Pediatric Patients. J. Pediatr. 2017, 190, 21-26.e7. [CrossRef] [PubMed]

23. Hoshal, S.G.; Samuel, B.P.; Schneider, J.R.; Mammen, L.; Vettukattil, J.J. Regression of massive cardiac rhabdomyoma on everolimus therapy. Pediatr. Int. 2016, 58, 397-399. [CrossRef] [PubMed] 